\title{
När blir det plagiat? - En tvärsnittsstudie av studenters färdigheter och förmågor gällande fusk i form av plagiat
}

\author{
Tom S. Karlsson \\ Göteborgs universitet
}

\begin{abstract}
Den här artikeln berör situationer då plagiat kan uppstå. Mer specifikt handlar artikeln om studenters färdigheter och förmågor när det kommer till plagiering eller situationer som skulle kunna förstås som plagiering. En enkät med nio olika situationer skapades i syfte att kartlägga studenters förmåga att identifiera när det kan handla om plagiat. 634 studenter på två olika institutioner vid Göteborgs universitet svarade på enkäten. Resultat och analys visar att studenter generellt hade god förmåga att identifiera enklare fall av plagiat, men klarade sig sämre i mer komplexa fall. Resultaten pekar vidare på att det framförallt är yngre studenter (födda på 90-talet) och akademiskt oerfarna som har lägre träffsäkerhet i sin identifikation. Artikeln avslutas med en reflektion kring undervisning och examination och lyfter särskilt fram tre delar: (i) vikten av att prata om plagiat, (ii) vikten av att arbeta med akademisk integritet och (iii) vikten av att arbeta med akademiskt oerfarna.
\end{abstract}

Nyckelord: Plagiat, akademisk ohederlighet, undervisning, examination, fusk

\section{INLEDNING}

Enligt högskolelagen (1992:I434) ska studier som bedrivs på universitet och högskolor leda till att studenter utvecklar en förmåga till kritiska bedömningar och självständighet, vilket i sin tur kan leda till utveckling av förmågor att möta ett arbetsliv som står i ständig förändring. Utvecklandet av ett kritiskt förhållningssätt innebär inte enbart ett ifrågasättande av rådande normer utan handlar också om förmågan att värdera åsikter och kunskaper på ett sådant sätt att vi fattar genomtänkta beslut. Ett viktigt högskolepedagogiskt verktyg i detta avseende är skrivandet och läsandet av olika typer av texter. Dels kräver vi att studenterna läser texter från erfarna akademiker, dels så kräver vi att de skriver och läser, kontinuerligt genom sin utbildning, egna texter. Syftet är att utveckla studenternas förmåga till reflektion, källkritik och djupinlärning (Mayer, 2002; Ramsden, 1992, 2003). Detta syfte möter en verklighet där studenterna vägs och värderas utifrån individuella prestationer, där låga resultat kan tolkas som ett misslyckande såväl akademiskt som privat.

En strategi, eller fenomen, som kan kopplas till detta är det växande problemet med akademisk ohederlighet inom högre utbildning. Beteendet har uppmärksammats såväl i Sverige som internationellt, där studenter medvetet eller omedvetet fuskar för att få ett betyg de annars inte skulle ha fått, eller alls klara sig genom sin utbildning (Ashworth m.fl., 1997; Martin, Rao \& Sloan, 2009; Park, 2003). Enligt Universitetskanslersämbetets (UKÄ) sammanställningar under perioden 2005 till 2015 har mängden ärenden som behandlats av lärosätenas lokala disciplinnämnder kommit att fördubblas. ${ }^{.}$Från en nivå om 44I ärenden under 2005 redovisar UKÄ i sin sammanställning att motsvarande siffra för 2015 uppgick till 880 ärenden. Den i särklass

*Författarkontakt: tom.karlsson@spa.gu.se

Artiklar och reflektioner är kollegialt granskade. Övriga bidragstyper granskas av redaktionen. Se www.hogreutbildning.se ISSN 2000-7558

(C2019 Tom S. Karlsson. This is an Open Access article distributed under the terms of the Creative Commons Attribution-NonCommercial 4.0 International License (https://creativecommons.org/licenses/by-nc/4.0/), allowing third parties to share their work (copy, distribute, transmit) and to adapt it, under the condition that the authors are given credit, that the work is not used for commercial purposes, and that in the event of reuse or distribution, the terms of this license are made clear.

Citation: Tom S. Karlsson (2019) "När blir det plagiat? - En tvärsnittsstudie av studenters färdigheter och förmågor gällande fusk i form av plagiat», Högre utbildning, 9(2), 32-47. http://dx.doi.org/10.23865/hu.v9.1645 
vanligaste orsaken till att ärenden tas upp i lärosätenas disciplinnämnder är sådana ärenden som har med misstänkt plagiering att göra. ${ }^{2}$

Tabell I. Sammanställning av redovisade disciplinärenden vid statliga högskolor och universitet (Högskoleverket 2009; Universitetskanslerämbetet 2013, 2015, 20I7)

\begin{tabular}{lccc}
\hline År & Disciplinärenden & Avstängningar & Varningar \\
\hline 2005 & $44 \mathrm{I}$ & 340 & IOI \\
2006 & 482 & 377 & I05 \\
2007 & 437 & 310 & $\mathrm{I} 27$ \\
2008 & 543 & 417 & $\mathrm{I} 26$ \\
2009 & 508 & 379 & $\mathrm{I} 29$ \\
2010 & 750 & 591 & $\mathrm{I} 59$ \\
2011 & 790 & 639 & I5I \\
2012 & $80 \mathrm{I}$ & 621 & I80 \\
2013 & 736 & 555 & I8I \\
2014 & 773 & 618 & I55 \\
2015 & 880 & 663 & 217 \\
\hline
\end{tabular}

Plagiering handlar i grund och botten om att en text eller en idé används av en person i syfte att framställa den som sin egen (Heckler \& Forde, 2015; Park, 2003). Då avses ett medvetet agerande i syfte att vilseleda en annan part, t.ex. examinatorn på en kurs, att tro att den text eller idé som presenterats har skapats av individen själv och ingen annan. Det handlar då om en akademisk ohederlighet (Birks m.fl., 20I8; Trost, 2009) som skapar stora problem för individen såväl som samhället (Gullifer \& Tyson, 20IO; Youmans, 20II). Studier har visat att plagiering under studietiden leder till en negativ inlärning (Isserman, 2003) som också riskerar återkomma i ett senare arbetsliv (Martin m.fl., 2009). På samhällsnivå finns det risk för att bristande arbete med akademisk ohederlighet leder till såväl problem med kvaliteten hos arbetskraften som att förtroendet för universitetet som kunskapsinstitution sjunker (Marsden, Carroll \& Neill, 2005).

Det finns en lång rad av internationella studier som redovisat anledningar till varför studenter tar till fusk (Ashworth m.fl., I997; Franklyn-Stokes \& Newstead, I995; Heckler \& Forde, 2015; McCabe \& Trevino, I997; Newstead, Franklyn-Stokes \& Armstead, I996) specifikt i form av plagiat (Breen \& Maassen, 2005; Jereb m.fl., 20I8; Jereb m.fl., 20I7; Park, 2003) i sina studier. Andra studier (Clarkeburn \& Freeman, 2008; Howard \& Davies, 2009; Luke, 2014) visar att studenternas färdigheter och förmågor i akademiskt skrivande i många fall brister, vilket ökar risken för att plagiera. Utmaningen för högre utbildning blir i dessa fall att introducera studenter i akademiskt skrivande och ge dem verktyg för att förstå hur det utförs (Chatterjee, 2007). Kopplingen mellan studenters färdigheter och förmågor med risk för plagiering har diskuterats även i svensk kontext (Hallonsten, 2007; Hult \& Hult, 2003) och det har också konstaterats att Sverige inte är undantag från den internationella trenden kring ökande antal av plagieringsfall (Trost, 2009). Undersökningar bland studenter på bl.a. Lunds universitet (20I7) och Högskolan i Skövde (20I8) visar att en tydlig majoritet anser att de behöver stöd för att lära sig hantera referenser samt läsa och skriva akademisk text.

Mot bakgrund av den internationella litteraturens intresse för brister i studenters färdigheter och förmågor kring när plagiat uppstår, fokuserar den här artikeln på att studera i vilken mån 
studenter kan identifiera olika textsituationer som plagiat. Syftet är att studera och diskutera studenters färdigheter och förmågor när det kommer till plagiering eller situationer som skulle kunna förstås som plagiering. I studien har studenter fått ta ställning till ett antal olika situationer, där varje situation bedömts som plagiat eller inte plagiat. På detta sätt kopplas den här artikeln till Trosts (2009) uppmaning om mer ingående studier i svenska lärmiljöer och bidrar till en tydligare förståelse för studenters färdigheter och förmågor kring plagiering. Studien bidrar vidare med förståelse för hur vi som akademiker kan arbeta med komplexa frågor kring akademisk ohederlighet i vår pedagogiska praktik. Detta görs genom en enkätstudie till studenter på olika utbildningsnivåer (grund- samt avancerad nivå) i tre olika ämnen på två institutioner vid Göteborgs universitet. ${ }^{3}$

Den här artikeln har disponerats enligt följande. Efter denna inledning följer en litteraturöversikt med fokus på fusk generellt och plagiering specifikt. Därefter presenteras studiens metod och genomförande följt av resultaten från den enkätstudie som genomfördes med 634 studenter. Slutligen diskuteras resultaten i relation till litteratur på området tillsammans med en reflektion kring vad resultaten har för bäring och inverkan på pedagogiskt arbete vid högre utbildning i Sverige.

\section{AKADEMISK OHEDERLIGHET I FORM AV PLAGIERING}

Akademisk ohederlighet är ett brett begrepp som omfattar olika former av bedrägliga beteenden inom ramen för den högre utbildningen. Vanligen diskuterar vi detta som fusk, där avsikten är att försöka vilseleda någon annan i syfte att få en fördel. I det här avsnittet görs en litteraturöversikt med fokus på att utreda vad som är känt kring plagiering mer specifikt. I den här litteraturöversikten diskuteras fyra olika områden för att förtydliga det rådande kunskapsläget: (i) varför plagierar studenter, (ii) vem är det som plagierar, (iii) var går gränsen för plagiering och (iv) hur länkas studenters färdigheter och förmågor till kunskap om plagiering?

Akademisk ohederlighet i form av plagiering är ett fenomen som kommit att breda ut sig så väl internationellt (Franklyn-Stokes \& Newstead 1995) som i Sverige (Hallonsten, 2007; Hult $\&$ Hult, 2003; Trost, 2009). Förståelsen för varför studenter väljer att agera ohederligt är relativt väl belagt. Det kan handla om en önskan om högre betyg (Newstead m.fl., 1996) i en kraftigt tävlingsinriktad miljö (Heckler \& Forde, 2015). Men det handlar också om misslyckanden med att hantera de tidsramar som man fått (Ashworth m.fl., 1997), att man ser det som en enkel utväg eller att man helt enkelt saknar respekt för kursen eller kursledarna på en viss utbildning (Franklyn-Stokes \& Newstead, 1995). Skaar och Hammer (2013) visar i en studie från Norge hur studenterna använde plagiering som en strategi för att undvika att spendera för mycket tid på uppgiften. I en studie från nordamerikansk kontext kunde man också finna att en orsak till fusket berodde på att studenterna använder studierna som ett s.k. "stop-gap", en plats mellan andra sysselsättningar, och därför hade mindre anledning att engagera sig i lärandet (Newstead m.fl., 1996).

I litteraturen återfinner vi även studier som försökt identifiera vilka grupper av individer som mer sannolikt kommer att ägna sig åt fusk utifrån ett mer generellt perspektiv. En tydlig majoritet av dessa studier är baserade i en nordamerikansk kontext. Genom att studera studenters självvärdering kring fuskande har man kunnat visa på att män mer frekvent bekänner att de ägnat sig åt ohederligt beteende jämfört med kvinnor (Birks m.fl., 20I8; Franklyn-Stokes \& Newstead, 1995; Jereb m.fl., 20I8; Jereb m.fl., 2017), att det är vanligare bland yngre eller akademiskt oerfarna studenter (Birks m.fl., 20I8; Newstead m.fl., 1996) och att studenter med studieovana eller svårigheter att delta i lärandet (Franklyn-Stokes \& Newstead, 1995) agerar 
ohederligt. Hallonsten (2007) visade i en studie bland 463 studenter på Lunds universitet att så många som var tredje person angav att de hade fuskat genom plagiering. I Hallonstens studie framgår att den vanligaste formen av plagiering handlade om att skriva om texter man hittat med egna ord men inte lägga till referens. Internationella studier framhåller även att aktiviteter vid sidan av studierna (det som på engelska benämns som "extracurricular activities") kan fungera som en faktor för att studenter fuskar (McCabe \& Trevino, 1997). En trolig anledning till detta är att tiden för studier begränsas och plagiering ses som en möjlig utväg för att bli klar med studieuppgifter.

För den här studien är fusk i form av plagiering av särskilt intresse. Park (2003) menar att vi bör förstå plagiering som en form av ett mer utbrett beteende inom ramen för akademisk ohederlighet; en form som kommit att bli den vanligaste formen av fusk (Breen \& Maassen, 2005). Plagiering har beskrivits som en farsot (Petress, 2003) som hotar dels den akademiska professionen, dels högre utbildning som kunskapsinstitution (Marsden m.fl., 2005), hela tiden ökar i omfång (Park, 2003) och kommit att bli särskilt observerbar i takt med att digitala verktyg eller tekniska hjälpmedel utvecklats (Ashworth m.fl., 1997).

Med plagiering avses vanligen ett beteende där en individ stjäl en text eller idé från någon annan i syfte att presentera den som sin egen. Selwyn (2008, s. 465) som citeras i Heckler och Forde (2015, s. 6I) beskriver och definierar plagiat som en:

... reproduction of text from other academic sources, such as journal articles, books, or lecture notes without adequate acknowledgement of the source, copying some or all of students' assignments and even having assignments 'ghost-written' by other authors.

Liksom i fallet med akademisk ohederlighet på ett övergripande plan har studier försökt identifiera varför studenter plagierar. I många fall handlar det om ett medvetet försök att vilseleda, men det finns också tecken på att gränsen för när något blir plagiat inte alltid är tydlig för studenterna. Ashworth m.fl. (I997, s. I9I) kallar detta för "the hazy nature of plagiarism", där studenterna till vissa delar kan tyckas famla i ett mörker i sina försök att konstruera en text som är originell i såväl uttryck som tanke. Det finns situationer där studenterna kan ha en teoretisk förståelse för vad som är plagiat, men sedan misslyckas med att översätta detta till en akademisk praktik (Risquez, O’Dwyer \& Ledwith, 2013), vilket leder till omedveten (Brown \& Murphy, 1989) eller oavsiktlig (Ashworth m.fl., I997; Perry 20I0; Risquez m.fl., 2013) plagiering.

Arbetet med att försöka komma tillrätta med plagiering är svårt och många gånger tidskrävande. En springande punkt är att få studenterna att förstå att de källor och referenser som används ska stödja och inte ersätta de egna idéerna (Park, 2003; White, 1993). Sådana pedagogiska insatser i form av att stärka studenternas färdigheter och förmågor kan stödja studenter som inte nödvändigtvis är medvetna om att de fuskar (Hallonsten, 2007). Studier har visat att många studenter som påbörjar en högre utbildning saknar en förmåga att läsa stora mängder text och därefter kunna skriva en adekvat sammanfattning (se t.ex. Howard \& Davies, 2009). Andra menar att initialt bristande språkkunskaper kan skapa situationer där studenterna plagierar (möjligen omedvetet) eftersom de saknar en djupare kunskap om det språk som studierna bedrivs på (Skaar \& Hammer, 2013; Song-Turner, 2008). Att plagiat alls uppstår kan alltså handla om ett bedrägligt beteende (som diskuterats ovan), men också om att studenterna inte fått tillräcklig tid för att utveckla sina färdigheter och förmågor gällande just de här situationerna. Chatterjee (2007) menar att studenters plagiat kan förstås som ett 
försök, ett första steg om man så vill, till att lära sig hantera det akademiska språket och dess intertextualitet.

Utifrån ett pedagogiskt perspektiv blir det viktigt hur vi utformar möjligheterna för att stödja studenterna i deras utveckling. Idén om att omfamna den akademiska praktiken av att producera originella texter och idéer bör alltså vara en integrerad del av den (ut)bildning som studenterna får. Att studenterna också efterlyser detta framkommer med tydlighet i studentbarometrar vid Högskolan i Skövde och Lunds universitet (Högskolan i Skövde, 20r8; Lunds universitet, 2017).

Tydligt arbete med akademisk integritet (Gullifer \& Tyson, 20I4) och regler (Chen \& Chou, 20I7) bör komma tidigt i utbildningen för att ge störst effekt (Breen \& Maassen, 2005). Newstead m.fl. (1996) föreslår att arbetet med att fördjupa studenternas motivation i form av lärandemål, till skillnad från prestationsmål, kan skapa en bättre situation i arbetet mot studenters plagiering. Andra studier har visat på vikten av att konstruera policydokument kring arbetet mot och hanteringen av plagiat (Husain, Al-Shaibani \& Mahfoodh, 20I7; McCabe \& Trevino, 1997), även om det finns indikationer på att enbart hälften av studenterna faktiskt läser dessa typer av dokument (Gullifer \& Tyson, 20I4). Ett sätt att komma till rätta med denna senare problematik är att aktivt arbeta med att påminna studenterna, genom hela utbildningen, om det problematiska med plagiat (Youmans, 20II). Andra sätt har varit att aktivt arbeta med detekteringssystem (såsom exempelvis Urkund), men det är tveksamt om sådana system faktiskt får studenter att plagiera mindre (Youmans, 20II). Clarkeburn och Freeman (2008) menar att arbetet med att stödja, påminna och förklara den akademiska kontexten behöver vara aktivt och återkommande genom utbildningen, samtidigt som högre utbildning behöver fortsätta arbeta med att identifiera och hantera fuskandet. Ett sådant arbete slutar inte nödvändigtvis på lägre nivåer, utan behöver fortsätta även på forskarutbildningsnivå samt den kontinuerliga fortbildningen bland forskare.

Att arbeta med frågor kring plagiat är centralt inte bara för den högre utbildningen utan också för samhället i stort. Några studier pekar på att studenters användande av plagiering, medveten eller omedveten, som ett verktyg för att klara sina studier också kommer att fortplanta sig till deras vidare arbetsliv (Martin m.fl., 2009; Youmans, 20II). Insatser som implementeras inom ramen för utbildningen bör kontinuerligt bilda studenterna så att de kan skapa verktyg för att förhindra såväl medveten som omedveten plagiering.

\section{METOD OCH GENOMFÖRANDE}

För att undersöka studenternas färdigheter och förmågor när det kommer till specifikt plagiat konstruerades och distribuerades en enkät. Enkäten omfattade ett antal olika situationer som har direkt koppling till deras arbete med att läsa och skriva akademisk text. Genom att låta studenterna besvara enkäten möjliggjordes kartläggning av graden av träffsäkerhet i formen av att kunna identifiera när en situation är eller inte är att betrakta som plagiat. Eftersom studien har varit explorativ har inte några specifika hypoteser formulerats eller testats.

Enkäten konstruerades med fyra bakgrundsfrågor samt nio möjliga plagiatsituationer. I bakgrundsfrågorna efterfrågades (i) kön, (ii) ålder, (iii) erfarenhet av tidigare studier i högre utbildning samt i förekommande fall (iv) hur många högskolepoäng som avklarats före nuvarande utbildning. De nio plagiatsituationerna togs fram genom att använda frågor som återges i Urkunds text Plagiathandboken (Urkund 2008-20II). Samtliga situationer kunde besvaras med svaren (i) plagiat, (ii) inte plagiat, (iii) osäker och (iv) vet ej. De nio olika situationerna som studenterna fick ta ställning till presenteras nedan i tabell 2. Innan vi diskuterar 
respondenternas deltagande, kan det vara på sin plats att kort reflektera över de situationer som inkluderats i studien.

Av de nio situationerna är det två alternativ som kan behöva förklaras något närmre. Situationerna F samt I är snarlika, med skillnaden att specificeringen gällande citattecken saknas i situation F. Detta innebär att situation F är en plagiatsituation, men kan framstå som lite klurig för respondenten. I dataunderlaget går det att se hur vissa studenter $(\mathrm{n}=85 ; \mathrm{I} 3,4 \%)$ har strukit över svaret och ändrat. Man kan anta att respondenten blivit uppmärksammad på detta när situation I besvarats. Om det korrigerade svaret gjorts till att situation $F$ är plagiat, har detta kodats som ett korrekt svar. När det gäller situation $G$ finns det en osäkerhet kring om situationen är ett plagiat eller inte. Om texten sedan tidigare har publicerats kan det komma att betraktas som en egenplagiering, medan det $\mathrm{i}$ andra fall inte är plagiering men anses vara fusk eller akademiskt ohederligt. I kodning av materialet har rätt svar konstruerats som osäkert, men just den här situationen kan innehålla viss felmarginal. Båda situationerna har dock behållits i enkäten för att kunna användas som ett underlag för vidare diskussion med studenterna i syfte att skapa en lärandesituation kring plagiatsituationer.

\section{Tabell 2. Nio möjliga plagiatsituationer, frän Plagiathandboken (Urkund 2008-20II)}

\begin{tabular}{|c|c|c|}
\hline & Fråga & Plagiat? \\
\hline A & Skriva av eller kopiera ett kortare stycke ordagrant från en källa utan att ange vem originalförfattaren är. & Ja \\
\hline B & I samförstånd med sin handledare/lärare arbeta vidare med en text man själv skrivit tidigare. & Nej \\
\hline $\mathrm{C}$ & Översätta en annan författares text till ett annat språk och använda resultatet utan att ange källan. & $\mathrm{Ja}$ \\
\hline $\mathrm{D}$ & $\begin{array}{l}\text { Använda en existerande text utan att ange vem originalförfattaren är, men göra små justeringar } \\
\text { som att ändra ordföljder och meningsbyggnad, byta ut ord mot synonymer, ta bort eller lägga till } \\
\text { enstaka ord o.d. }\end{array}$ & $\mathrm{Ja}$ \\
\hline E & $\begin{array}{l}\text { Att läsa flera texter och arbeta om innehållet till en ny text som inte liknar någon av de ursprungliga } \\
\text { källorna med mer än att några ord eller mening är de samma, utan att ange någon av källorna. }\end{array}$ & $\mathrm{Ja}$ \\
\hline F & Skriva av en max 3-4 meningar lång text ordagrant och ange vem originalförfattaren är i anslutning till texten. & $\mathrm{Ja}$ \\
\hline G & Översätta en text man själv författat till ett annat språk och använda resultatet. & Osäkert \\
\hline $\mathrm{H}$ & Bygga vidare på en text som tidigare har betygsatts utan att ange vilka delar som är gamla. & $\mathrm{Ja}$ \\
\hline I & $\begin{array}{l}\text { Skriva av en max } 3-4 \text { meningar lång text ordagrant, markera med citationstecken och ange vem } \\
\text { originalförfattaren är i anslutning till texten. }\end{array}$ & Nej \\
\hline
\end{tabular}

Enkäten delades ut till studenter som påbörjade eller fortsatte sina studier inom ämnena (i) offentlig förvaltning, (ii) svenska språket eller (iii) svenska som andraspråk. ${ }^{4}$ Deltagandet var frivilligt och genomfördes på plats i undervisningssammanhang på schemalagd undervisningstid efter att de blivit informerade om studiens syfte och fått information om att inga individuella data skulle komma att publiceras, utan att all analys och presentation sker på aggregerad nivå. Deltagande var anonymt så till vida att inga namn eller annan identifierbar information fanns på de enkäter som deltagarna lämnade in. För att kunna genomföra analys baserat på (i) ämne och (ii) erfarenheter av studier noterades kursbeteckning på de enkäter som delades ut till studenterna. Totalt deltog 634 respondenter, varav $4 \mathrm{I} 4$ var kvinnor och 202 var män ( 6 respondenter angav annat som kön, 7 ville inte ange och 5 hade inte angett kön). En majoritet av respondenterna utgjordes av studenter i ämnet offentlig förvaltning $(n=428,67,5 \%)$. De studenter som deltagit i studien kommer från olika bakgrunder, med olika erfarenheter och i olika åldrar, med den gemensamma faktorn att alla läser en utbildning på ett svenskt universitet. 
Tabell 3. Sammanställning över deltagande respondenter

\begin{tabular}{lcccccc}
\hline & Kvinnor & Män & Annat & Vill ej ange & 99 & Totalt \\
\hline Offentlig förvaltning & 265 & I54 & 2 & 5 & 2 & 428 \\
Svenska som andraspråk & 88 & I9 & 3 & 2 & & II2 \\
Svenska språket & $6 \mathrm{I}$ & 29 & 2 & & 3 & 94 \\
Totalt & 4I 4 & 202 & 6 & 7 & 5 & 634 \\
\hline
\end{tabular}

För att kunna kartlägga studenternas sammanlagda färdighet och förmåga för plagiatsituationer konstruerades två olika typer av beroende variabler. För detta första kodades alla nio situationer från enkäten utifrån ett korrekt eller felaktigt givet svar. Detta innebar konkret att ett korrekt givet svar gavs ett (I) poäng och felaktiga svar gavs noll (o) poäng. Detta benämns som situationsindex $\mathrm{i}$ analys och diskussion och anger den träffsäkerhet (i relativa termer) som respondenterna uppvisar för situationerna A-I var för sig. Situationsindexet kan variera mellan noll (o) och ett (I). För det andra togs ett sammantaget värde av alla situationsindex fram för att möjliggöra en sammantagen bedömning av studenternas plagiatbedömning. Detta benämns som resultatindex $\mathrm{i}$ analys och diskussion. Resultatindex kan variera mellan noll (o) och nio (9). I syfte att kontrollera den interna reliabiliteten i de underliggande variablerna (plagiatsituationerna) testades dessa genom Cronbachs alfa (s.k. "test-retest-reliabilitet"). Detta resulterade i ett värde om, 837 vilket får anses vara ett godtagbart mått för explorativa studier av den här sorten (Hair m.fl., 1998). ${ }^{5}$

Fyra oberoende variabler konstruerades vidare i syfte att kartlägga om det fanns statistiskt signifikanta skillnader i resultatindex eller situationsindex; (i) kategorisering av ålder, (ii) könstillhörighet, (iii) erfarenheter av studier och (iv) ämnestillhörighet. Såväl situations- som resultatindex analyserades genom att jämföra medelvärde inom och mellan de grupper som konstruerats i de oberoende variablerna. Skillnader i varians genomfördes via envägs variansanalys (ANOVA) i syfte att klarlägga kartläggningen av studenternas förståelse för plagiatsituationer. Av redaktionella och utrymmesmässiga skäl har ANOVA-tabellerna inte bilagts artikeln men kan fås av författaren vid förfrågan. Löpande presenteras dock resultat- och situationsindex samt eventuella statistiska signifikansnivåer för de olika analyserna.

Som en avslutande del kan det finnas anledning att kort reflektera över generaliserbarheten av studiens resultat. Även om antalet respondenter har varit relativt stort $(n=634)$, omfattar studien enbart studenter vid två olika institutioner på ett svenskt lärosäte. Att hävda att de specifika resultat skulle gälla för studenter nationellt eller globalt vore naturligtvis att dra det hela för långt. För den typen av generalisering skulle fler och större undersökningar behövas.

\section{RESULTAT}

I följande resultatavsnitt presenteras medelvärden och varianser för situationsindex och resultatindex. Som helhet uppvisar studenterna relativt god förmåga att identifiera tydliga fall av plagiat. Hallonsten (2007) visar på liknande resultat från sin studie, där studenterna identifierar de allvarligaste formerna av plagiat som sådana där man lämnar någon annans text som sin egen (situationerna A och C). Något mer komplexa eller svårtolkade situationer har studenterna utifrån ett generellt perspektiv svårare med. För att få en djupare förståelse för hur studenternas färdigheter och förmågor kring plagiat är kommer resultaten att presenteras utifrån eventuella skillnader relaterade till (i) ämne, (ii) ålder, (iii) kön och (iv) erfarenheter av studier. I det efterföljande diskussionsavsnittet kommer resultaten att ställas i relation till presenterad litteraturöversikt. 
ÄMNE

I den första analysen (se tabell 4 nedan) som genomfördes riktades fokus på respondenternas ämneshemvist. Distinktion gjordes i detta fall mellan (i) offentlig förvaltning, (ii) svenska språket och (iii) svenska som andraspråk. Resultatindex varierar mellan som högst 5,87 och som lägst 5,4I (5,5I totalt) och det finns signifikanta skillnader mellan grupperna. Studenter inom svenska språket $(5,53)$ och offentlig förvaltning $(5,4 \mathrm{I})$ uppvisar lägre genomsnittliga resultatindex jämfört med studenter inom svenska som andraspråk $(5,87)$. Det är dock enbart skillnaden i resultatindex mellan studenter i svenska som andraspråk och offentlig förvaltning som är statistiskt signifikanta $(, 460 ; \mathrm{p}=, \mathrm{OI} 3)$.

Tabell 4. Resultat-och situationsindex för ämnesfördelning

\begin{tabular}{|c|c|c|c|c|c|c|c|c|c|c|}
\hline Ämne & 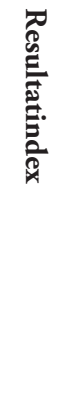 & 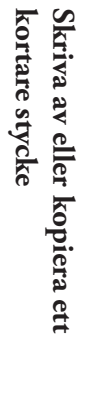 & 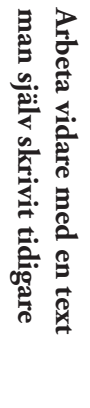 & 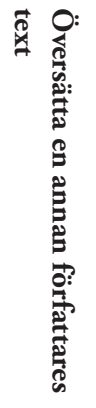 & 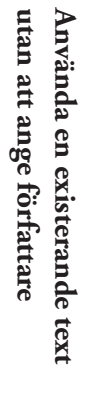 & 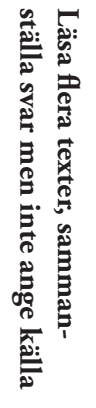 & 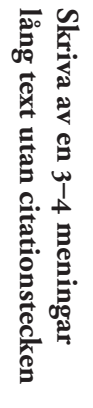 & 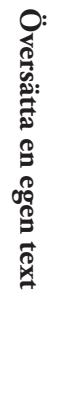 & 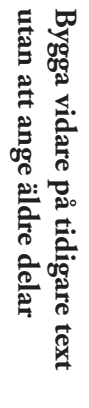 & 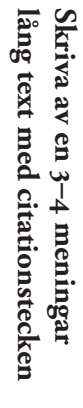 \\
\hline SVA & 5,87 & ,95 & ,62 & ,92 & ,79 &, 50 &, 33 &, 22 &, 63 & ,90 \\
\hline SV & 5,53 & ,98 &, 83 & ,93 & ,70 &, 30 & ,2I &, 22 &, 45 & ,93 \\
\hline OFF & $5,4 \mathrm{I}$ & ,96 &, 75 & ,93 & ,60 &, 35 & ,3I & ,I6 &, 42 & ,93 \\
\hline Total & $5,5 \mathrm{I}$ & ,96 & ,74 &, 93 &, 65 &, 37 &, 30 & ,I8 & ,46 & ,92 \\
\hline
\end{tabular}

När det gäller situationsindex mellan de tre grupperna återfinner vi fyra variabler som har signifikanta skillnader. Studenter i svenska som andraspråk har större träffsäkerhet jämfört med studenter i svenska språket ( $\mathrm{p}=, 008 ; \mathrm{p}=$,oI9) och offentlig förvaltning ( $\mathrm{p}=$, oII; $\mathrm{p}<$, ,o०) när det handlar om plagiatsituationerna $\mathrm{E}$ och $\mathrm{H}$. Samma grupp är vidare säkrare än studenter inom offentlig förvaltning $(\mathrm{p}=<, \mathrm{O}, \mathrm{O}) \mathrm{i}$ identifikationen av plagiat $\mathrm{i}$ att använda en något justerad text utan att ange källa (situation D). När det gäller träffsäkerheten kring plagiat i att arbeta vidare med en egen text i samråd med sin handledare eller lärare är studenter i svenska som andraspråk mer osäkra jämfört med studenter i svenska språket ( $\mathrm{p}=, \mathrm{oI} 9)$ och offentlig förvaltning $(\mathrm{p}=, \mathrm{o}, \mathrm{o})$.

\section{KÖN}

I den andra analysen (tabell 5 nedan) riktades fokus mot att identifiera eventuella skillnader i resultatindex och situationsindex som baserat på könstillhörighet. Analysen visar att det inte finns några statistiskt signifikanta skillnader i respondenternas resultatindex, vilket varierar mellan som högst 5,86 och som lägst 5,32 (totalt 5,5I). I respondenternas situationsindex är det endast en situation som uppvisar signifikant olika värde; plagiatsituation I. I dessa situationer är kvinnliga respondenter ( $\mathrm{p}=, \mathrm{oI} 6)$ något säkrare $\mathrm{i}$ att identifiera att det inte handlar om plagiat jämfört med manliga respondenter. Det bör dock påpekas att såväl kvinnliga $(, 94)$ som manliga $(, 88)$ respondenter har ett högt situationsindex gällande just den frågan. 
Tabell 5. Resultat- och situationsindex för könsfördelning

\begin{tabular}{|c|c|c|c|c|c|c|c|c|c|c|}
\hline Kön & 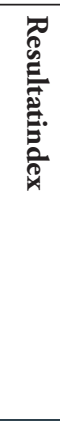 & 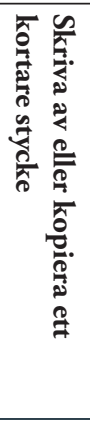 & 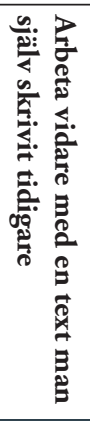 & 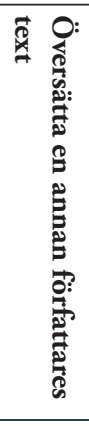 & 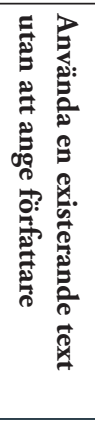 & 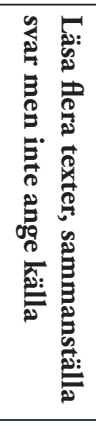 & 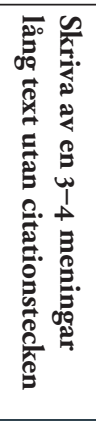 & 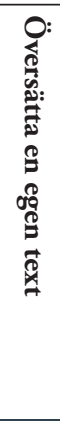 & 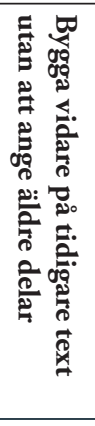 & 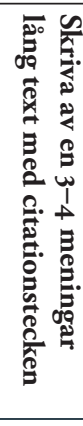 \\
\hline Kvinna & 5,59 & ,97 & 7,75 & ,93 & ,65 &, 38 &, 32 &, 20 &, 44 & ,94 \\
\hline Man & 5,32 & ,94 &, 72 &, 92 & ,64 &, 34 &, 25 & , I6 &, 47 & ,88 \\
\hline Annat & 5,67 &, 83 &, 83 & $\mathrm{I}, \mathrm{OO}$ &, 33 &, 33 &, 50 &, 33 &, 50 & $\mathrm{I}, \mathrm{OO}$ \\
\hline Vill ej ange & 5,86 &, 86 &, $7 \mathrm{I}$ & $\mathrm{I}, \mathrm{OO}$ &, 86 &, 43 &, 43 & , ০০ &, $7 \mathrm{I}$ &, 86 \\
\hline Total & $5,5 \mathrm{I}$ &, 96 &, 74 &, 93 &, 65 &, 37 &, 30 & ,I8 &, 46 &, 92 \\
\hline
\end{tabular}

\section{ÅLDER}

Gällande ålder (tabell 6 nedan) analyserades om det fanns skillnader i resultatindex och situationsindex mellan olika ålderskategorier. Vad det gäller resultatindex, som varierar mellan 5,79 (respondenter födda på 80-talet) som högst och 5,35 (respondenter födda mellan 1940 och 1969) som lägst, fanns inga signifikanta skillnader.

I analysen av skillnader gällande situationsindex var det situation $\mathrm{D}$ samt $\mathrm{H}$ där respondenterna uppvisade skillnader. I situation D finner vi att respondenter som var födda på 90-talet svarade signifikant sämre på denna fråga jämfört med respondenter födda på 8o-talet $(\mathrm{p}=, \mathrm{ooI})$ och respondenter födda på 70-talet $(\mathrm{p}=, \mathrm{or} 4)$. Respondenter födda under 90-talet hade i denna situation endast en träffsäkerhet om $58 \%$. I situation $\mathrm{H}-$ att arbeta vidare med en text utan att ange detta - var respondenter födda på 9o-talet signifikant sämre ( $\mathrm{p}=, 034)$ jämfört med respondenter födda på 80-talet. Det ska dock påpekas att 90-talisternas träffäkerhet (medel om 47\%) låg i linje med respondenter födda före 1979, även om inga fler signifikanta resultat kunde finnas.

Tabell 6. Resultat- och situationsindex för ålderskategorier

\begin{tabular}{|c|c|c|c|c|c|c|c|c|c|c|}
\hline Ålderskategorier & 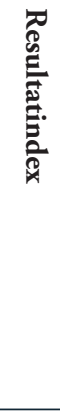 & 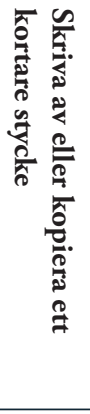 & 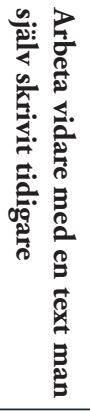 & 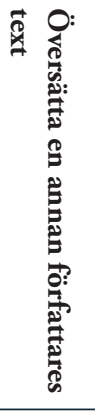 & 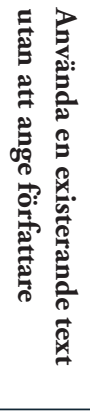 & 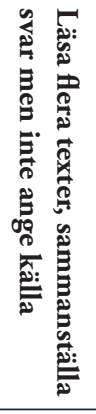 & 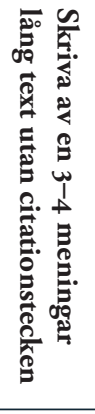 & 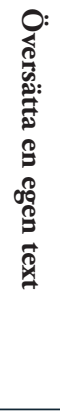 & 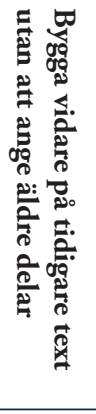 & 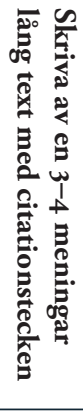 \\
\hline 1960 & 5,35 & ,96 & ,65 & ,9I &, 74 &, 35 &, $\mathrm{I} 3$ &, $\mathrm{I7}$ &, 48 & ,96 \\
\hline 1970 & 5,49 & ,9I & ,7I & ,94 &, 83 & ,3I & ,20 &, 29 &, 40 & 89 \\
\hline 1980 & 5,79 & ,97 & ,68 & ,96 &, 78 & ,4I & ,29 & ,I8 & ,60 & ,9I \\
\hline 1990 & 5,42 & ,96 &, 75 & ,93 &, 58 &, 34 &, 30 & , I8 &, 44 & ,93 \\
\hline Total & 5,48 &, 96 & ,73 & ,94 & ,64 &, 35 & ,29 & ,19 & ,47 & ,93 \\
\hline
\end{tabular}




\section{ERFARENHETER AV STUDIER}

För den här studiens (explorativa) syfte är det av särskilt intresse att undersöka om tidigare erfarenhet av högre studier medför en säkrare förmåga att identifiera plagiatsituationer. För att undersöka detta har erfarenhet av studier operationaliserats på två sätt (se tabell 7 nedan). För det första har studenter som angett att de har studerat tidigare separerats från dem som angett att de inte studerat vid högre utbildning före sin nuvarande kurs. Här finner vi statistiskt signifikanta skillnader i träffsäkerhet gällande såväl resultatindex $(\mathrm{p}<, 0$,o) som i tre olika plagiatsituationer: $\mathrm{C}(\mathrm{p}=, \mathrm{OIO}), \mathrm{D}(\mathrm{p}<, \mathrm{O}) \mathrm{O})$ och $\mathrm{E}(\mathrm{p}<, \mathrm{OOO})$. I samtliga fall är träffsäkerheten för studenter utan tidigare studieerfarenhet lägre än för studenter som haft studieerfarenhet före det nuvarande programmet eller den nuvarande kurs som de läser.

För det andra undersöktes gruppen av respondenter som angett att de inte hade erfarenhet av högre utbildning före sin nuvarande kurs. För denna grupp avgjordes vilken termin de befann sig på inom ramen för sin utbildning. Vid en jämförelse av respondenternas erfarenhet i termer av terminstillhörighet återfanns inga statistiskt signifikanta skillnader i resultatindex eller situationsindex.

Tabell 7. Resultat-och situationsindex för erfarenheter av studier

\begin{tabular}{|c|c|c|c|c|c|c|c|c|c|c|}
\hline Erfarenhet & 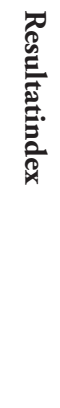 & 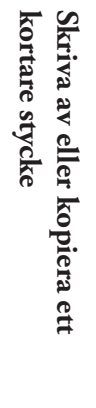 & 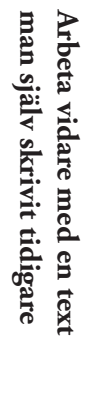 & 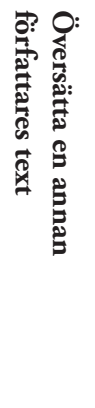 & 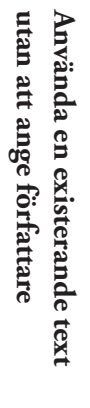 & 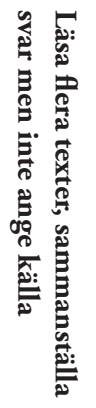 & 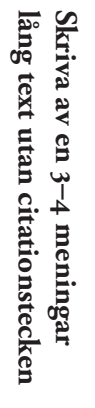 & 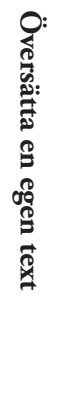 & 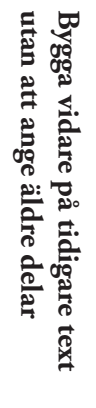 & 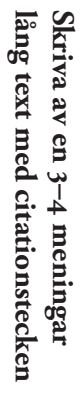 \\
\hline Har läst tidigare & 5,74 & 96 &, 73 & ,95 & ,74 & 44 &, 32 & , I9 &, 48 & ,93 \\
\hline Har inte läst tidigare & 5,08 & ,95 &, 76 & ,90 &, 48 & 24 &, 26 & ,I7 &, 43 & ,90 \\
\hline Total & 5,50 & ,96 &, 74 & ,93 &, 65 &, 37 &, 30 & ,I8 & ,46 & ,92 \\
\hline
\end{tabular}

\section{SVAGA SITUATIONSINDEX}

Som ett sista led i resultaten studerades särskilt om det fanns indikationer att vissa situationsindex var särskilt svaga i jämförelse med andra (se tabell 8 nedan). Detta operationaliserades genom att identifiera de situationsindex som hade lägre medelvärde än 0,5 (det vill säga lägre träffsäkerhet än 50\%). I denna analys återfanns situationerna $\mathrm{E}($ medel = ,37), F (medel = ,30), $\mathrm{G}$ (medel = ,I8) och H (medel = ,46) som särskilt svaga.

Tabell 8. Deskriptiv analys av individuella situationstindex

\section{Descriptive Statistics}

\begin{tabular}{|c|c|c|c|c|c|}
\hline & $\mathbf{N}$ & Minimum & Maximum & Mean & Deviation \\
\hline Resultatindex & 634 & o & 9 & $5,5 \mathrm{I}$ & $\mathrm{I}, 533$ \\
\hline Skriva av eller kopiera ett kortare stycke & 634 & o & I & ,96 &, 202 \\
\hline $\begin{array}{l}\text { Arbeta vidare med en text man själv } \\
\text { skrivit tidigare }\end{array}$ & 634 & o & I &, 74 & ,44I \\
\hline
\end{tabular}


Tabell 8. (Continued)

\begin{tabular}{|c|c|c|c|c|c|}
\hline \multicolumn{6}{|c|}{ Descriptive Statistics } \\
\hline & $\mathbf{N}$ & Minimum & Maximum & Mean & $\begin{array}{c}\text { Std. } \\
\text { Deviation }\end{array}$ \\
\hline Översätta en annan författares text & 634 & o & I & ,93 & ,254 \\
\hline $\begin{array}{l}\text { Använda en existerande text utan att } \\
\text { ange författare }\end{array}$ & 634 & o & I & ,65 & , 477 \\
\hline $\begin{array}{l}\text { Läsa flera texter, sammanställa svar men } \\
\text { inte ange källa }\end{array}$ & 634 & o & I &, 37 &, 483 \\
\hline $\begin{array}{l}\text { Skriva av en } 3-4 \text { meningar lång text utan } \\
\text { citationstecken }\end{array}$ & 634 & o & I &, 30 &, 458 \\
\hline Översätta en egen text & 634 & o & I &, $\mathrm{I} 8$ & ,386 \\
\hline $\begin{array}{l}\text { Bygga vidare på tidigare text utan att } \\
\text { ange äldre delar }\end{array}$ & 634 & o & I & ,46 & ,499 \\
\hline $\begin{array}{l}\text { Skriva av en } 3-4 \text { meningar lång text med } \\
\text { citationstecken }\end{array}$ & 634 & o & I & ,92 & ,270 \\
\hline Valid N (listwise) & 634 & & & & \\
\hline
\end{tabular}

\section{AVSLUTANDE DISKUSSION OCH SLUTSATSER}

Den här studien har syftat till att studera och diskutera studenters färdigheter och förmågor när det kommer till plagiering eller situationer som skulle kunna förstås som plagiering. Detta har gjorts genom att låta studenter besvara en enkät med nio (9) olika textsituationer som kan uppstå eller förekomma inom ramen för det arbete som görs i högre utbildning. Resultaten har analyserats utifrån ett explorativt perspektiv, där skillnader mellan (i) ämnestillhörighet, (ii) könstillhörighet, (iii) ålderskategorier och (iv) utbildningserfarenhet har redovisats. I det här avsnittet diskuteras resultaten och ställs i relation till den litteratur som finns på området.

När det gäller utfallet kring resultatindex, vilket alltså är det sammanvägda resultatet för de nio situationerna, så visar studien att det finns skillnader mellan studenterna i fråga om ämne och utbildningserfarenhet. Studien visar att studenter i ämnet svenska som andraspråk har större träffsäkerhet gällande plagiat samtidigt som studenter med tidigare erfarenheter av högre studier har större träffsäkerhet. När det gäller den senare frågan kring utbildningserfarenhet så har tidigare studier kunnat visa att akademiskt oerfarna studenter (Birks m.f., 20I8; Newstead m.fl., 1996) i högre grad är representerade bland dem som säger sig vara villiga att fuska. Andra studier (Franklyn-Stokes \& Newstead, 1995) har argumenterat för att studieovana kan vara en bidragande faktor till varför man agerar i fusk. I förhållande till den här studien så har detta viss bäring. Vad som särskilt karakteriserar studenter i ämnet svenska som andraspråk är att de till hög grad utgörs av studenter med tidigare studievana inom ramen för högre utbildning. Så mycket som $82 \%(n=9 I)$ av studenterna i svenska som andraspråk anger att de har tidigare studievana, vilket kan jämföras med $79 \%$ för studenter i svenska $(n=64)$ och $56,6 \%$ för studenter i offentlig förvaltning $(n=240)$. En bidragande orsak till att det finns skillnader i resultatindex mellan grupperna skulle därmed kunna sökas i skillnaderna gällande akademisk erfarenhet. När det kom till skillnader i fråga om könstillhörighet och ålderskategori återfanns inga statistiskt signifikanta resultat på de beräknade resultatindexen. Kön har tidigare framhållits som en faktor för fusk (Birks m.fl., 2018; Franklyn-Stokes \& Newstead, I995; Jereb m.fl., 20I8; Newstead m.fl., 1996), men i den här studien har studenternas övergripande färdighet och förmåga att identifiera plagiat inte funnits vara signifikant olika. På samma sätt är det med ålder, där vissa studier pekat 
på att fusk är vanligare bland yngre studenter (Birks m.fl., 20I8; Newstead m.fl., I996), men där den här studien inte finner detta gällande det sammanvägda resultatindexet. Där det beräknade resultatindexet ger en första kartläggning för studenters förståelse för plagiat kan situationsindex ge en mer ingående kunskap kring träffsäkerheten i olika situationer.

Den plagiatsituation som framstod som mest skild mellan grupperna var situation D; att använda en existerande text utan att ange originalförfattare, men göra små förändringar gällande ord eller meningsuppbyggnad. Framförallt var det studenter i ämnet svenska som andraspråk (SVA) som hade signifikant högre träffsäkerhet gällande detta. Men frågan kom även att ge utslag för ålder, där studenter födda på 90-talet hade sämre träffsäkerhet än studenter födda på 70- och 8o-talen, och utbildningserfarenhet, där de som svarat nej gällande tidigare akademisk erfarenhet uppvisade sämre träffsäkerhet. Att ämnet svenska som andraspråk faller bättre ut i förhållande till övriga två ämnen kan sökas i dessa två andra kategorier. Studenterna som studerar svenska som andraspråk är jämförelsevis äldre och mer akademiskt erfarna. En annan plagiatsituation som framstod som intressant utifrån ett jämförandeperspektiv var situation E; att läsa flera texter och arbeta om innehållet till en ny text som inte liknar någon av de ursprungliga källorna mer än marginellt, men missa att ange källor. Även här visar studien på att studenter i svenska som andraspråk samt akademiskt mer erfarna studenter har större träffsäkerhet.

Utöver de statistiskt signifikanta skillnaderna som diskuterats ovan är det värt att ägna lite tid åt sådana situationsindex som faller särskilt illa ut. Med detta menas att medelvärdet understiger 0,5 vilket motsvarar lägre än $50 \%$ träffsäkerhet. Framförallt gäller det situation E (läsa flera texter och sammanställa kort egen text), F (skriva in ett citat men utelämna citattecken) samt $\mathrm{H}$ (bygga vidare på tidigare examinerad text utan att ange detta). Till viss del är detta mer komplexa plagiatsituationer som kräver ett stort kunnande från studenterna. Att det inte finns signifikanta skillnader mellan grupperna antyder också att problematiken - för så måste den förklaras givet den mycket låga träffsäkerheten - är allmänt utbredd bland studenter. Risquez m.fl. (2013) visar i sin studie att en anledning för varför plagiat förekommer bland studenterna är för att de inte har förmågan att identifiera annat än de mer uppenbara fallen av att direkt kopiera text från en källa. Resultaten från den här studien pekar i samma riktning, och visar på vikten av att kontinuerligt tala om och exemplifiera plagiatsituationer under utbildningens gång (Breen \& Maassen, 2005; Trost, 2009). Resultaten kan också tolkas som att intresset kring plagiat eller att förstå vad som utgör plagiat minskar i takt med att komplexiteten ökar. En sådan tolkning styrks genom att respondenterna har en extremt hög träffsäkerhet kring den första situationen (A), där det handlar om att direkt skriva av eller kopiera en text ordagrant (situationsindex om ,96 över alla respondenter). Huruvida det handlar om studenternas bristande engagemang och ovilja att förstå situationerna (Ellery, 2008 som citeras av Risquez m.fl., 2013), eller om det handlar om en genuin oförståelse för vad som utgör plagiat (Ashworth m.fl., 1997) kan dock inte besvaras utifrån de data som samlats in i den här studien.

Att plagiat är ett växande problem för högre utbildning är välkänt (Ashworth m.fl., 1997; Park, 2003; Trost, 2009). Den här studien har särskilt avgränsat sig till en kartläggning av studenternas färdigheter och förmågor när det kommer till att kunna identifiera en möjlig plagiatsituation. Studiens resultat har bäring på såväl undervisning som examination vid högre utbildning. Detta kan sammanfattas i tre punkter: (i) vikten av att prata om plagiat, (ii) vikten av att arbeta med akademisk integritet och (iii) vikten av att arbeta med akademiskt oerfarna. I den följande reflektionen utvecklas dessa tre delar. 


\section{Vikten av att prata om plagiat}

Studien visar på att plagiat är något som inte är alldeles självklart för studenter. De klarar väl av att identifiera de mer uppenbara fallen, men fallerar att identifiera mer komplexa eller oklara situationer. Hallonsten (2007) har kommit fram till liknande resultat från en studie vid Lunds universitet. I såväl den här som i Hallonstens studie har studenterna relativt klart för sig att det är felaktigt utifrån ett akademiskt perspektiv att skriva av en text, kopiera den från en digital källa eller översätta en text och använda den som vore den deras egen. Det är rimligt att tänka sig att studenter har fått med sig den här informationen från grundskola eller gymnasium eftersom träffsäkerheten är relativt stabil oavsett ämnestillhörighet, kön, ålder eller studieerfarenhet. Bristerna när det gäller studenternas träffsäkerhet uppstår vid något svårare eller otydliga fall. Att så många av studenterna visade svårigheter med att identifiera situation E ("Läsa flera texter, sammanställa svar men inte ange källa") upplevs särskilt graverande. Detta pekar på betydelsen av att prata om och problematisera plagiat och akademiskt skrivande återkommande under utbildningens gång, gärna så tidigt i utbildningen som möjligt (Breen \& Maassen, 2005; Gullifer \& Tyson, 20IO; 2014).

Plagiat kan förstås olika beroende på i vilka kontexter de uppstår eller var man kommer från. Det kan därför vara viktigt att problematisera även kulturella aspekter av det akademiska skrivandet. Chatterjee (2007) menar att det finns ett värdefullt lärande i studenternas plagiering när vi förstår skrivandet som att lära sig det akademiska språket. Att imitera skapar möjligheter för studenterna att skapa bättre färdigheter och förmågor, men riskerar samtidigt att bryta mot de konventioner som råder. Det finns ett behov av att prata om plagiat och vara tydlig i vilka regler som gäller (Chen \& Chou, 20I7).

\section{Vikten av att arbeta med akademisk integritet}

Risquez m.fl. (2013) konstaterar att bara för att studenten har en teoretisk förståelse för vad som utgör plagiat är det inte säkert att han eller hon har kunskapen kring vad detta innebär praktiskt. Det vill säga att det kan finnas ett behov av att arbeta praktiskt och pragmatiskt (Jereb m.f.,, 20I8) med dessa frågor som en integrerad del i utbildningen. I ett sådant arbete är det troligen otillräckligt att göra engångsinsatser i form av enstaka föreläsningar där endast rätt och fel radas upp. McCabe och Trevino (1997) menar att införandet av en s.k. hederskodex bland studenter, där en ökande andel internaliserar idén om att akademisk ohederlighet inte accepteras, kan påverka synen på plagiering. Samtidigt bör vi reflektera över vilka resurser som ställs till förfogande för att stödja studenternas utveckling av sina färdigheter och förmågor. Undersökningar visar (Högskolan i Skövde 20I8; Lunds universitet 20I7) att studenterna värdesätter och efterfrågar ökat stöd $i$ att lära sig korrekt referenshantering och tekniker för att läsa och skriva akademisk text, men färre och färre timmar allokeras i undervisning för att kunna möjliggöra detta. Hallonsten (2007) fann att ett skäl till att plagiering hade kunnat öka var att studentgrupperna blivit större och att tiden inte längre räckte till för att skapa en bra grund för hur man skriver akademisk text. Expansionen av den högre utbildningen genom t.ex. internationalisering skapar också utmaningar i form av att studenter med sämre språkfärdigheter börjar studera (Song-Turner, 2008; Skaar \& Hammer, 20I3).

I arbetet med att öka det pedagogiska arbetet med akademisk integritet kan det också finnas skäl att adressera förekomsten av tidsrationalitet som kan prägla vissa studentgrupper. Plagiat bör aldrig vara en strategi (Skaar \& Hammer, 2013) eller genväg (Luke, 20I4) för att bli klar snabbt med ett akademiskt arbete. Här kan den ökade digitaliseringen i samhället vara en utmaning. Szabo och Underwood (2004) har visat att studenter upplever det som mindre problematiskt 
att kopiera text om den finns på internet. Tillgången till digitala källor är en bidragande orsak till att plagiering har kommit att öka (Ashworth m.fl., 1997; Clarkeburn \& Freeman, 2008). Att arbeta med akademisk integritet som en integrerad del av utbildningen möjliggör att studenterna kan förstå att källor som ska vara stödjande och inte ersättande för egna tankar (White, 1993) och fördjupade färdigheter och förmågor kring hur dialog mellan akademiska texter kan skapas (Chatterjee, 2007).

\section{Vikten av att arbeta med akademiskt oerfarna}

Den här studien visar att studenter som har tidigare akademisk erfarenhet har en högre träffsäkerhet i sin identifiering av möjliga plagiatsituationer. Även om urvalet som använts är begränsat, finns det anledning att tro att detta är ett mer generellt mönster (Birks m.f., 20I8; Franklyn-Stokes \& Newstead, I995; Jereb m.fl., 20I8; Newstead m.fl., 1996). Resultatet borde inte vara särskilt överraskande (att utbildning har betydelse), men förtjänar inte desto mindre att lyftas fram. Med goda färdigheter och förmågor kring referenshantering och att kunna läsa och skriva akademisk text minskar risken att plagiera av misstag. Andra aspekter bör naturligtvis beaktas här såsom socioekonomisk bakgrund, skäl för studier, språkliga förmågor osv. som alla kan inverka på om en student (råkar) plagiera.

Utöver att tidigt arbeta med plagiat inom ramen för undervisning (Breen \& Maassen, 2005; Gullifer \& Tyson, 20IO; 20I4) är det också av vikt att examinationen återspeglar vårt tydliga ställningstagande mot plagiering. Trost (2009) menar att ett sätt att göra detta på ett konstruktivt sätt är att integrera formativa bedömningar av mindre vikt som en naturlig del i examinationen. Här avses alltså sådan examination som kan möjliggöra god återkoppling till studenterna så att eventuellt felaktigt beteende kan avhjälpas (eller avläras) utan att det inverkar negativt på studentens slutbetyg. Det finns studier som visar att ju högre press som sätts kring prestationer (Newstead m.fl., 1996) eller betyg (Ashworth m.fl., 1997), desto mer ökar risken för att använda sig utav plagiat som en strategi för att klara studierna. Den här studien visar att studenter med mer akademisk erfarenhet möjligen tagit till sig detta, medan yngre, mer akademiskt oerfarna studenter har lägre träffsäkerhet i sin identifikation av möjliga plagiatsituationer.

\section{FÖRFATTARPRESENTATION}

Tom S. Karlsson är universitetslektor i offentlig förvaltning på Förvaltningshögskolan vid Göteborgs universitet. Har har bred pedagogisk erfarenhet av att undervisa i organisering, styrning och redovisning på grund- och avancerad nivå och vidare stor erfarenhet av att handleda och examinera uppsatser.

\section{TACK}

Den här artikeln har till mycket stor grad utvecklats positivt som en följd av de kommentarer som getts i samband med den anonyma granskningen inför publikation. Tidigare manusutkast har presenterats på pedagogiska seminarier vid Göteborgs universitet och de kommentarer som getts där har också haft inverkan på hur artikeln utvecklats. Jag vill också passa på att tacka de kollegor på Förvaltningshögskolan och institutionen för svenska språket som hjälpte till att dela ut och samla in enkäter i samband med undervisning. Tack!

\section{NOTER}

I. UKÄ har i dagsläget ingen statistik gällande disciplinärenden på statliga högskolor för perioden 2016 till 2017 (mailkorrespondens 2018-10-04 med Pontus Kyrk, verksjurist på Universitetskanslersämbetet).

2. För Göteborgs universitet, där den här studien genomförts, ser trenden likadan ut. Efter samtal med universitetsjuristerna gavs information om att disciplinnämnden hanterade 45 ärenden under 2015 ( $34 \mathrm{av}$ stängda), 86 ärenden under 2016 ( 50 avstängda), 79 ärenden under 2017 ( 45 avstängda) samt 77 ärenden 
under 2018 (fram till 5 oktober; 48 avstängda) (mailkorrespondens 2018-10-o5 med Ida Wernwik, jurist på Forsknings- och innovationskontoret, Göteborgs universitet).

3. Vid studiens genomförande fanns även ett pedagogiskt syfte som handlade om att uppmärksamma studenter på plagiering som fenomen och genom detta proaktivt påverka studenterna till att inte hamna i sådana fällor som förknippas med plagiatsituationer (Breen \& Maassen 2005; McCabe \& Trevino 1997). Genom att genomföra den enkät som studien bygger på skapades ett lärandemoment för studenterna där de gavs möjlighet att diskutera och reflektera kring svårigheterna med att definiera vad som är och inte är plagiering. Detta andra syfte behandlas dock inte vidare i den här artikeln, men har haft stor inverkan på det pedagogiska arbetet lokalt.

4. Följande förkortningar används: Offentlig förvaltning, OFF; Svenska som andraspråk, SVA; Svenska språket, SV.

5. Alla beräkningar har utförts med SPSS Statistics version 24 .

\section{REFERENSER}

Ashworth, P., Bannister, P., Thorne, P., \& Unit, S. o. t. Q. R. M. C. (1997). Guilty in whose eyes? University students' perceptions of cheating and plagiarism in academic work and assessment. Studies in Higher Education, 22(2), 187-203.

Birks, M., Smithson, J., Antney, J., Zhao, L., \& Burkot, C. (2018). Exploring the paradox: A cross-sectional study of academic dishonesty among Australian nursing students. Nurse education today, 65, 96-101.

Breen, L., \& Maassen, M. (2005). Reducing the incidence of plagiarism in an undergraduate course: The role of education. Issues in Educational Research, 15(1), 1.

Brown, A. S., \& Murphy, D. R. (1989). Cryptomnesia: Delineating inadvertent plagiarism. Journal of Experimental Psychology: Learning, Memory, and Cognition, 15(3), 432.

Chatterjee, M. (2007). Learning to Avoid Plagiarism. International Journal of Learning, 13(10).

Chen, Y., \& Chou, C. (2017). Are we on the same page? College students' and faculty's perception of student plagiarism in Taiwan. Ethics \& Behavior, 27(1), 53-73.

Clarkeburn, H., \& Freeman, M. (2008). To plagiarise or not to plagiarise: An online approach to improving and motivating honest academic writing. International Journal of Management Education, 6(3), 21-33.

Ellery, K. (2008). Undergraduate plagiarism: A pedagogical perspective. Assessment \& Evaluation in Higher Education, 33(5), 507-516.

Franklyn-Stokes, A., \& Newstead, S. E. (1995). Undergraduate cheating: who does what and why? Studies in Higher Education, 20(2), 159-172.

Gullifer, J. M., \& Tyson, G. A. (2010). Exploring university students' perceptions of plagiarism: A focus group study. Studies in Higher Education, 35(4), 463-481.

Gullifer, J. M., \& Tyson, G. A. (2014). Who has read the policy on plagiarism? Unpacking students' understanding of plagiarism. Studies in Higher Education, 39(7), 1202-1218.

Hair, J. F. J., Andersson, R. E., Tatham, R. L., \& Black, W. C. (1998). Multivariate data analysis (5:th ed.). London: Prentice-Hall.

Hallonsten, O. (2007). Kampen om kunskapsmarknaden: Om plagiat bland högskolestudenter. In W. Agrell (Ed.), Forskningens gråzoner (pp. 67-102). Stockholm: Carlsson Bokförlag.

Heckler, N. C., \& Forde, D. R. (2015). The role of cultural values in plagiarism in higher education. Journal of Academic Ethics, 13(1), 61-75.

Howard, R. M., \& Davies, L. J. (2009). Plagiarism in the Internet age. Educational Leadership, 66(6), 64-67.

Hult, Å., \& Hult, H. (2003). Att fuska och plagiera: Ett sätt att leva eller ett sätt att överleva? : Linköping University Electronic Press.

Husain, F. M., Al-Shaibani, G. K. S., \& Mahfoodh, O. H. A. (2017). Perceptions of and attitudes toward plagiarism and factors contributing to plagiarism: A review of studies. Journal of Academic Ethics, 15(2), 167-195.

Högskolan i Skövde. (2018). Studentbarometern. Retrieved from http://www.his.se/PageFiles/55793/ Studentbarometer\%20totalrapport_HS_webben.pdf

Högskoleverket. (2009). Disciplinärenden 2008 vid högskolor och universitet (Rapport 2009:14 R). Retrieved from Stockholm: 
Isserman, M. (2003). Plagiarism: A lie of the mind. Chronicle of Higher Education, 49(34), B12.

Jereb, E., Urh, M., Jerebic, J., \& Šprajc, P. (2017). Gender differences and the awareness of plagiarism in higher education. Social Psychology of Education, 1-18.

Jereb, E., Perc, M., Lämmlein, B., Jerebic, J., Urh, M., Podbregar, I., \& Šprajc, P. (2018). Factors influencing plagiarism in higher education: A comparison of German and Slovene students. PloS one, 13(8), e0202252.

Luke, B. (2014). Misconduct versus misunderstood? Scaffolding education and learning. Accounting Education, 23(4), 383-385.

Lunds universitet. (2017). Studentbarometern. Retrieved from https://www.medarbetarwebben.lu.se/sites/ medarbetarwebben.lu.se/files/studentbarometern_2017_rapport.pdf

Marsden, H., Carroll, M., \& Neill, J. T. (2005). Who cheats at university? A self-report study of dishonest academic behaviours in a sample of Australian university students. Australian Journal of Psychology, 57(1), 1-10.

Martin, D. E., Rao, A., \& Sloan, L. R. (2009). Plagiarism, integrity, and workplace deviance: A criterion study. Ethics \& Behavior, 19(1), 36-50.

Mayer, R. E. (2002). Rote Versus Meaningful Learning. Theory Into Practce, 41(4), 226-232.

McCabe, D. L., \& Trevino, L. K. (1997). Individual and contextual influences on academic dishonesty: A multicampus investigation. Research in higher education, 38(3), 379-396.

Newstead, S. E., Franklyn-Stokes, A., \& Armstead, P. (1996). Individual differences in student cheating. Journal of Educational Psychology, 88(2), 229-241.

Park, C. (2003). In other (people's) words: Plagiarism by university students--literature and lessons. Assessment \& Evaluation in Higher Education, 28(5), 471-488.

Perry, B. (2010). Exploring academic misconduct: Some insights into student behaviour. Active learning in higher education, 11(2), 97-108.

Petress, K. C. (2003). Academic dishonesty: a plague on our profession. Education, 123(3), 624-627.

Ramsden, P. (1992). Learning and Teaching in Higher Education. London \& New York: Routledge.

Ramsden, P. (2003). Learning to Teach in Higher Education (2nd ed.). London: RoutledgeFalmer.

Risquez, A., O’Dwyer, M., \& Ledwith, A. (2013). 'Thou shalt not plagiarise': from self-reported views to recognition and avoidance of plagiarism. Assessment \& Evaluation in Higher Education, 38(1), 34-43.

Selwyn, N. (2008). 'Not necessarily a bad thing ...': A study of online plagiarism amongst undergraduate students. Assessment \& Evaluation in Higher Education, 33(5), 465-479.

Skaar, H., \& Hammer, H. (2013). Why students plagiarise from the internet: The views and practices in three Norwegian upper secondary classrooms. International Journal for Educational Integrity, 9(2), 15-34.

Song-Turner, H. (2008). Plagiarism: Academic dishonesty or'blind spot'of multicultural education? Australian Universities' Review, The, 50(2), 39-50.

Szabo, A., \& Underwood, J. (2004). Cybercheats: Is information and communication technology fuelling academic dishonesty? Active learning in higher education, 5(2), 180-199.

Trost, K. (2009). Psst, have you ever cheated? A study of academic dishonesty in Sweden. Assessment \& Evaluation in Higher Education, 34(4), 367-376.

Universitetskanslerämbetet. (2013). Disciplinärenden 2012 vid universitet och högskolor (rapport 2013:6). Retrieved from Stockholm:

Universitetskanslerämbetet. (2015). Disciplinärenden 2014 vid universitet och högskolor (rapport 2015:6). Retrieved from Stockholm:

Universitetskanslerämbetet. (2017). En högskola fri frän fusk. Retrieved from http://www.uka.se/om-oss/ konferenser--seminarier/konferenser--seminarier/2017-10-09-en-hogskola-fri-fran-studentfusk.html

Urkund. (2008-2011). Plagiathandboken: Tips och råd till elever och studenter (V 1.6). Prio Infocenter AB. Stockholm.

White, E. M. (1993). Too many campuses want to sweep student plagiarism under the rug. Chronicle of Higher Education, 39(25), A44-A44.

Youmans, R. J. (2011). Does the adoption of plagiarism-detection software in higher education reduce plagiarism? Studies in Higher Education, 36(7), 749-761. 